\title{
The development of a legal framework for blood donation and blood safety in China over 24 years
}

\author{
Dajun Gao ${ }^{1}$, Heng Li2 $2^{2^{*}}$ and Kang Wang ${ }^{3^{*}}$
}

\begin{abstract}
Background: This study analyzes the regulation of and developments in blood donation in China from 1996 to 2019, and demonstrates the government's efforts to improve blood safety.

Results: Since the implementation of the Blood Donation Law in 1998, the number of blood donors in China increased by 275\% from 1998 to 2018 (from 4 million to 15 million). The principle of no-fault liability was proposed and has been applied since 2010 to the tort liability related to blood transfusion malpractice. In 2015, mutual blood donation accounted for $4.2 \%$ of the national collection. However, in some provinces of China, the percentage of mutual blood donation increased from 9.3 to $35.6 \%$ in 2016. The National Health Commission canceled mutual blood donation in March of 2018. Since 2015, nucleic acid amplification testing has become a routine test item for screening blood.
\end{abstract}

Conclusions: The Chinese government institutionalized the voluntary non-remunerated donation principle, enacted regulations for the management of blood transfusion, and adopted advanced blood testing technology to sustain blood supply and ensure blood safety. Despite increased blood donation, blood shortages persist. The quality and safety of blood collection can be further improved through the cancellation of mutual blood donation and incentive measures for voluntary non-remunerated donation of blood, which needs facilitation by governmental legislation.

Keywords: Voluntary non-remunerated blood donation, China, Transfusion, Legislation, NAT

\section{Background}

From the 1980s to early 1990s, the shortage of blood and the introduction of new plasma collection technology in China created a big opportunity for paid donation, targeting the poor in rural areas. Blood with HIV/ AIDS, hepatitis $\mathrm{C}(\mathrm{HCV})$, and malaria, was common then, as were frequent cross infections [1,2]. Disorderly pricing, weak supervision, and negligence of tests

\footnotetext{
* Correspondence: liheng1985310@sina.com; kangwang@live.com

${ }^{2}$ School of Public Health, Shanghai Jiao Tong University School of Medicine, Shanghai, China

${ }^{3}$ Law School, Shanghai University of Political Science and Law, Shanghai, China

Full list of author information is available at the end of the article
}

directly resulted in hepatitis B (HBV) and HIV epidemics, which were transmitted through blood collection and transfusion in some regions $[3,4]$. In the mid1990s, an outbreak of HIV infection among paid plasma donors in Anhui and Henan Provinces in China was confirmed [5-7]. Blood safety required more attention and improvement in China, and the Chinese government gradually adopted a series of legislations and policies to improve blood safety.

To solve the problem of blood safety, China implemented the Law of the People's Republic of China on Blood donation (Blood Donation Law) in 1998, and institutionalized the principle of voluntary nonremunerated blood donation (VNRBD) by learning from

(c) The Author(s). 2020 Open Access This article is licensed under a Creative Commons Attribution 4.0 International License, which permits use, sharing, adaptation, distribution and reproduction in any medium or format, as long as you give appropriate credit to the original author(s) and the source, provide a link to the Creative Commons licence, and indicate if changes were made. The images or other third party material in this article are included in the article's Creative Commons licence, unless indicated otherwise in a credit line to the material. If material is not included in the article's Creative Commons licence and your intended use is not permitted by statutory regulation or exceeds the permitted use, you will need to obtain permission directly from the copyright holder. To view a copy of this licence, visit http://creativecommons.org/licenses/by/4.0/. The Creative Commons Public Domain Dedication waiver (http://creativecommons.org/publicdomain/zero/1.0/) applies to the data made available in this article, unless otherwise stated in a credit line to the data. 
international experience. VNRBD is an important measure for ensuring blood quality and safety. Blood safety has undergone significant changes in China since 1998. Currently, most scholars have reached a consensus regarding VNRBD and its foundation for a safe and sustainable blood supply [8]. In a review published by the World Health Organization (WHO), experts declared that without a system based on VNRBD, no country can provide sufficient blood for all patients who require transfusion [8]. China had a total of 459 blood centers in 2010, including 355 specialized blood stations and 104 blood stations in hospitals [9]. The number of blood donations and the volume of blood collection in China have been on the rise for 20 consecutive years [10]. In 1998, the number of unpaid blood donors nationwide was around 4 million, reaching nearly 15 million in 2018. In 1998, the volume of national blood collection was nearly 5 million units, reaching 25 million units by 2018 [11]. According to the WHO's 2016 Global Status Report on Blood Safety and Availability, apart from increased VNRBD, the number of blood donations, and volume of blood collection, blood safety has been improved by the blood nucleic acid test (NAT) technology adopted by China; and the clinical, rational use of blood has likewise significantly improved in China [12]. Despite more than 20 years of continuous improvement, there are still many shortcomings in blood safety in China, such as the increasing need for blood and blood products, the risk of transfusion-transmitted infections that lead to chronic blood shortages, unsafe blood products, and unsound clinical transfusion practices [13-18].

The recent status of blood donation and transfusion in China as per data from 1998 to 2019 is presented in this study. Furthermore, improvements and developments in blood donation mode, legal framework, policy, screening technology, and government management are demonstrated. The legal framework and policies on blood donation and transfusion have shown to be effective intervention mechanisms in ensuring blood quality and safety for more than 20 years. Development of the blood donation system in China is not only a reference model for other developing countries, but also an indicator of blood donation system problems and trends to help improve blood safety and availability in China.

\section{Methods}

The laws and regulations related to blood donation and transfusion that were implemented or revised from 1998 to 2019 in China were consolidated to expound on the current legal framework of blood transfusion and the roles of the government, blood stations, and hospitals in the management of clinical blood use. Documents on the laws, regulations, and notices were collected from official Chinese government websites, and the data on blood donation were obtained from official reports of the National Health Commission (NHC) from 1998 to 2019, the WHO's Global Database on Blood Safety from 1998 to 2011, and the 2016 Global Status Report on Blood Safety and Availability. We used "blood transfusion," "medical damage liability," "HBV," "HIV," "HCV," and "syphilis" as keywords to search litigation on the China Judgements Online Chinese court documents website. A total of 484 related cases were downloaded, and 301 of them qualified after screening.

\section{Results}

The change of blood donation modes from paid and mobilized unpaid to voluntary unpaid blood donation

In 1998, the Blood Donation Law became a symbol of the VNRBD system in China. VNRBD, family replacement/mutual blood donation (FRMBD), and employerorganized blood donation were the three types of blood donation programs permitted by the Blood Donation Law (see Fig. 1).

Employer-organized blood donation is an interim policy from paid blood donation to voluntary unpaid blood donation. In 2005, employer-organized blood donation, workers' blood donation as pre-arranged by the employer, and local blood stations, a semi-obligatory and mobilized unpaid mode, were banned by the Chinese government $[19,20]$. The reason for the ban was that those who donated blood, as required by their employer, were exposed to undue pressure and had higher rates of infectious disease markers compared to volunteer donors [21-24]. In fact, the cancellation of employerorganized blood donation meant that China implemented a voluntary unpaid donation system nationwide, thereby eliminating paid donation by 2005 . Of course, group voluntary blood donation, as a mode of VNRBD, is allowed in China, accounting for a large percentage of blood donation. Group blood donation has the advantage of being arranged in advance, making up for seasonal shortages in street blood collection and emergency mobilization [25].

There are three identified types of blood donors in the WHO Blood Safety and Availability Report: voluntary unpaid, family or replacement, and paid [12]. FRMBD is concerned with patients' family members, relatives, and friends - the unit to which he or she belongs in the community - under blood donation for mutual aid, thereby ensuring the supply of blood for citizens' clinical first-aid treatment [26]. FRMBD has been widely used for more than 20 years in China. Since 2009, the government of China has been giving increased attention to the proportion of FRMBD in blood collection. According to the NHC, the policy of FRMBD was canceled in 2018 across most regions, to improve blood quality and safety [27]. 


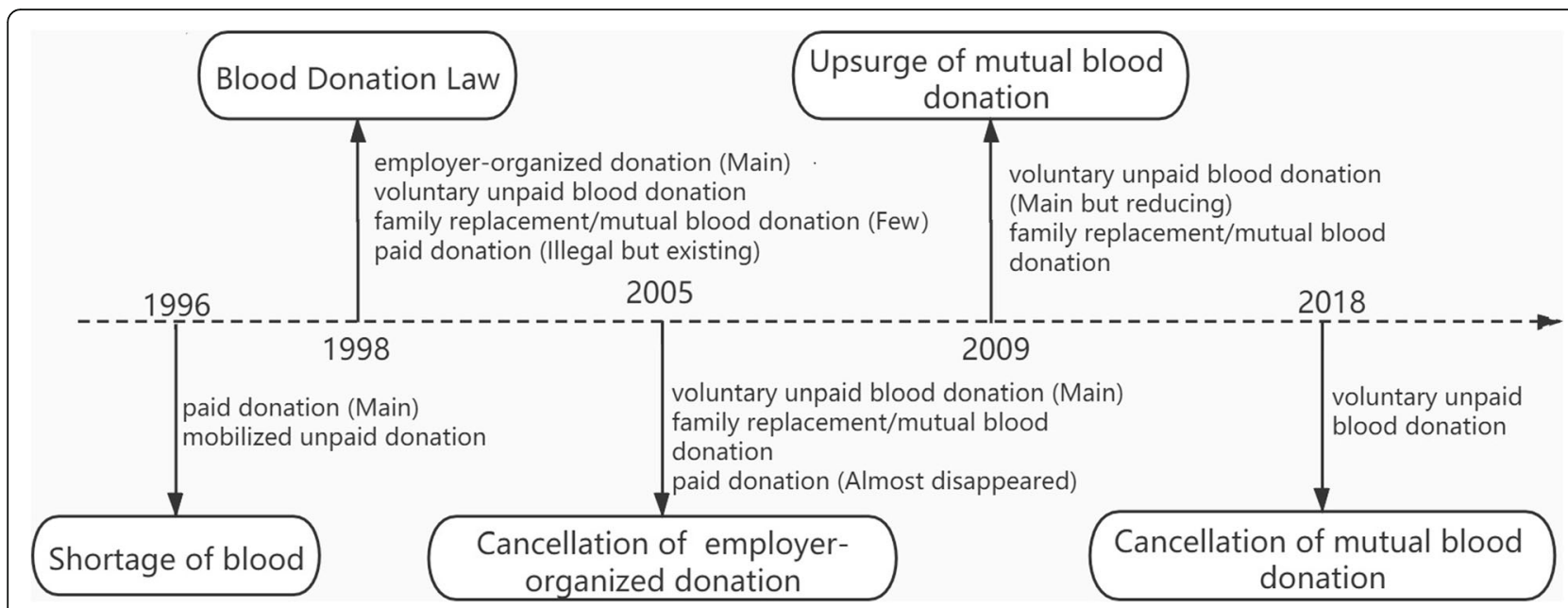

Fig. 1 Important policies in the development of China's blood donation modes

Roles of the government, blood centers, and medical institutions in the management of blood collection and transfusion

Blood must be used for official clinical activities. Any form of blood trade has been banned by the Chinese government to assure the quality and safety of blood collection, which were listed in accordance with blood-related laws and regulations (see Table 1). (From 1996 to 2013, China's National Health Administration agency was The Ministry of Health, and it was revoked and replaced by The National Health and Family Planning Commission from 2013 to 2018. Since March 2018, it has been replaced by the NHC). Even the importation and exportation of blood was forbidden in 2017 [28]. To encourage donation, the government provides voluntary blood donors with a holiday, a nutrition allowance, and priority access to blood transfusion during emergencies [29].

Blood centers serve as the main institution in the collection of blood. From 1993 to 1998, the establishment of blood centers has been consistently approved by the Red Cross Society in China [30]. After the Measures for Blood Center Administration (for Trial Implementation) were implemented in 1998, the blood center was defined as a nonprofit, public welfare organization, and its establishment was thereafter managed by the health administration department of the provincial government [31]. Blood centers provide the necessary health examination and blood collection service for voluntary unpaid blood donors, maintain blood supply for clinical use, and are responsible for storage and transportation [32]. Blood collected from donors is tested to avoid quality problems [33].

The medical institution is the only legal institution for the clinical use of blood. The Blood Donation Law stipulates that all blood and blood products must be tested before transfusion in medical institutions to ensure safety [34]. Other regulations and technical standards regarding blood centers and medical institutions are listed in Table 1. These guidelines and regulations have the effect of strengthening the management of blood collection and enhancing the level of blood safety.

\section{Significant increase in blood collection and supply}

Before 1998, the recruitment of blood donor volunteers was a very challenging endeavor in China. Traditional Chinese medicine holds that the loss of even a small amount of blood was harmful to health; this was also why paid blood donation was common at the time [3].

Since the 1998 implementation of the Blood Donation Law, and encouragement of unpaid blood donation through laws and policies [35], the number of unpaid blood donors and the amount of blood collected in China have been continuously increasing for 20 years (Fig. 2). (Data on 1998, 2010, 2011, 2014, 2015, 2016, 2017, 2018 from the NHC. Data on 2012 and 2013 from the Global Database on Blood Safety). The steady increase in the number of unpaid blood donors and the amount of blood collected has ensured the safe supply of blood from the source [11].

The proportion of unpaid blood donation, which was only $8 \%$ in 1998 , increased to $95.5 \%$ in 2005 . After 2009 , all clinical blood came from unpaid donation [36]. In response to the call of The Melbourne Declaration on $100 \%$ VNRBD and Blood Components, the Chinese government engaged in efforts to popularize VNRBD donors and joined the list of countries which reported almost 100\% blood collection in 2011 [37].

Through the establishment of a multi-level alarm mechanism when blood is in short supply, and the deployment of resources in different blood centers, seasonal, regional, and partial blood donation problems have been solved to a great extent. In 2015, 1.19 million units of blood were allocated across the country, 
Table 1 The Outline of Laws and regulations related to Blood Donation and Safety in China

\begin{tabular}{|c|c|c|c|c|c|}
\hline Type & Act & Legal sources & Implementation Years & Legislature & Main points \\
\hline \multirow[t]{10}{*}{$\begin{array}{l}\text { Specific } \\
\text { Legislations }\end{array}$} & $\begin{array}{l}\text { Regulations on Blood } \\
\text { Collection and Supply } \\
\text { Institution and Blood } \\
\text { Administration }\end{array}$ & Regulation & 1993 (1998 Expired) & $\begin{array}{l}\text { The Ministry } \\
\text { of Health }^{\mathrm{a}}\end{array}$ & $\begin{array}{l}\text { Permission of The } \\
\text { Blood Centre } \\
\text { Blood Donor Registration } \\
\text { Promotion of VNBD }\end{array}$ \\
\hline & $\begin{array}{l}\text { Detailed Rules for the } \\
\text { National Verification of } \\
\text { External Immunodiagnostic } \\
\text { Reagent for Blood Use }\end{array}$ & Regulation & 1994 & The Ministry of Health & $\begin{array}{l}\text { Test of HIV, HBV, HCV, } \\
\text { Syphilis }\end{array}$ \\
\hline & $\begin{array}{l}\text { Regulations on } \\
\text { Administration of Blood } \\
\text { Products }\end{array}$ & Regulation & 1996(2016 Revision) & $\begin{array}{l}\text { Instrumentalities } \\
\text { of the State Council }\end{array}$ & $\begin{array}{l}\text { Blood Product } \\
\text { Administration }\end{array}$ \\
\hline & Blood Donation Law & Law & 1998 & $\begin{array}{l}\text { Standing Committee } \\
\text { of the National } \\
\text { People's Congress }\end{array}$ & $\begin{array}{l}\text { VNBD System; Blood Only } \\
\text { for Clinical Use }\end{array}$ \\
\hline & $\begin{array}{l}\text { Measures for the } \\
\text { Administration of Blood } \\
\text { Centres (for Trial } \\
\text { Implementation) }\end{array}$ & Regulation & 1998 (2006 Expired) & The Ministry of Health & Blood Centre Administration \\
\hline & $\begin{array}{l}\text { regulations on Clinical Use } \\
\text { of Blood in Medical Institutions } \\
\text { (for Trial Implementation) }\end{array}$ & Regulation & 1999 (2012 Expired) & The Ministry of Health & Clinical Blood Use \\
\hline & $\begin{array}{l}\text { Technical Standards for the } \\
\text { Clinical Blood Transfusion }\end{array}$ & Regulation & 2000 & The Ministry of Health & $\begin{array}{l}\text { Corss-Match Test } \\
\text { Blood Transfusion Record }\end{array}$ \\
\hline & $\begin{array}{l}\text { Measures for the Administration } \\
\text { of Blood Centres }\end{array}$ & Regulation & $\begin{array}{l}2006 \text { (2009, 2016, } 2017 \\
\text { Amendment) }\end{array}$ & $\begin{array}{l}\text { The National Health } \\
\text { and Family Planning } \\
\text { Commission }^{\mathrm{a}}\end{array}$ & $\begin{array}{l}\text { Classification and } \\
\text { Management Of Blood } \\
\text { Centre } \\
\text { Blood Specimen Restoration } \\
2017 \text { Cancellation of Blood } \\
\text { Imports and Exports }\end{array}$ \\
\hline & $\begin{array}{l}\text { Provisions on Clinical Use } \\
\text { of Blood in Medical Institution }\end{array}$ & Regulation & 2012 & $\begin{array}{l}\text { The National Health } \\
\text { and Family Planning } \\
\text { Commission }\end{array}$ & $\begin{array}{l}\text { Clinical Blood Use } \\
\text { Emergency Blood Use }\end{array}$ \\
\hline & $\begin{array}{l}\text { Technical Operating Procedures } \\
\text { for Blood Centres (2019 Edition) }\end{array}$ & Regulation & $\begin{array}{l}2019 \text { Edition } \\
\text { (2005, 2012, } 2015 \\
\text { Edition Expired) }\end{array}$ & $\begin{array}{l}\text { The National Health } \\
\text { Commission }^{a}\end{array}$ & NAT in clinical use \\
\hline \multirow{4}{*}{$\begin{array}{l}\text { Other } \\
\text { Relative } \\
\text { Legislations }\end{array}$} & $\begin{array}{l}\text { Regulation on the Handling } \\
\text { of Medical Accidents }\end{array}$ & Regulation & 2002 & $\begin{array}{l}\text { Instrumentalities of } \\
\text { the State Council }\end{array}$ & Fault Compensation Liability \\
\hline & Tort Law & Law & 2010 & $\begin{array}{l}\text { Standing Committee } \\
\text { of the National } \\
\text { People's Congress }\end{array}$ & $\begin{array}{l}\text { Principle of No-Fault Liability } \\
\text { in Blood Transfusion Tort }\end{array}$ \\
\hline & $\begin{array}{l}\text { Pharmaceutical Administration } \\
\text { Law }\end{array}$ & Law & $\begin{array}{l}1984 \text { (2001, 2002, 2004, } \\
\text { 2016, 2017, } 2019 \\
\text { Revision) (2013 } \\
\text { Amendment) }\end{array}$ & $\begin{array}{l}\text { Standing Committee } \\
\text { of the National } \\
\text { People's Congress }\end{array}$ & $\begin{array}{l}\text { Blood Products Blood } \\
\text { Products Cannot Be } \\
\text { Commissioned Production } \\
\text { and Sell Online }\end{array}$ \\
\hline & $\begin{array}{l}\text { Prevention and Treatment } \\
\text { Of Infectious Diseases Law }\end{array}$ & Law & $\begin{array}{l}1989 \text { (2004 Revision) } \\
\text { (2013 Amendment) }\end{array}$ & $\begin{array}{l}\text { Standing Committee } \\
\text { of the National People's } \\
\text { Congress }\end{array}$ & $\begin{array}{l}\text { Ensure the Quality Of Blood } \\
\text { And Blood Products To } \\
\text { Prevent Transfusion- } \\
\text { Transmitted Diseases }\end{array}$ \\
\hline \multirow[t]{3}{*}{$\begin{array}{l}\text { Local } \\
\text { Legislation }\end{array}$} & $\begin{array}{l}\text { Regulations on Voluntary Blood } \\
\text { Donation By Citizens Of Beijing }\end{array}$ & Regulation & 1992 (1998 Expired) & $\begin{array}{l}\text { Beijing's Standing } \\
\text { Committee of the } \\
\text { National People's } \\
\text { Congress }\end{array}$ & $\begin{array}{l}\text { Promotion of voluntary } \\
\text { blood donors }\end{array}$ \\
\hline & $\begin{array}{l}\text { Regulations on Shenzhen } \\
\text { Special Economic Zone on } \\
\text { Citizen's Gratis of Blood } \\
\text { Donation and Blood } \\
\text { Management }\end{array}$ & Regulation & 1995 (2015 Expired) & $\begin{array}{l}\text { Shenzhen's Standing } \\
\text { Committee of the } \\
\text { National People's } \\
\text { Congress }\end{array}$ & Reimbursement of VNBD \\
\hline & $\begin{array}{l}\text { Regulations of Beijing } \\
\text { Municipality on Mobilizing }\end{array}$ & Regulation & 1998 (2006 Expired) & $\begin{array}{l}\text { Beijing's Standing } \\
\text { Committee of the }\end{array}$ & VNBD system \\
\hline
\end{tabular}


Table 1 The Outline of Laws and regulations related to Blood Donation and Safety in China (Continued)

\begin{tabular}{|c|c|c|c|c|c|}
\hline Type & Act & Legal sources & Implementation Years & Legislature & Main points \\
\hline & $\begin{array}{l}\text { and Arranging for Citizens to } \\
\text { Donate Blood }\end{array}$ & & & $\begin{array}{l}\text { National People's } \\
\text { Congress }\end{array}$ & \\
\hline & $\begin{array}{l}\text { Rules of Guangzhou Municipality } \\
\text { on Donation of Blood }\end{array}$ & Rules & $\begin{array}{l}2004 \text { (2015 } \\
\text { Amendment) }\end{array}$ & $\begin{array}{l}\text { Guangzhou Municipal } \\
\text { People's Government }\end{array}$ & Mutual Blood Donation \\
\hline & $\begin{array}{l}\text { Regulations of Nanning Municipality } \\
\text { on Blood Donation }\end{array}$ & Regulation & 2004 (2012 Revision) & $\begin{array}{l}\text { Nanning's Standing } \\
\text { Committee of the } \\
\text { National People's } \\
\text { Congress }\end{array}$ & VNBD system \\
\hline & $\begin{array}{l}\text { Measures of Beijing Municipality } \\
\text { for Administration of Blood } \\
\text { Donation }\end{array}$ & Rules & 2009 & $\begin{array}{l}\text { Beijing Municipal } \\
\text { People's Government }\end{array}$ & $\begin{array}{l}\text { VNBD publicity and the } \\
\text { service }\end{array}$ \\
\hline & $\begin{array}{l}\text { Regulations on Shenzhen } \\
\text { Special Economic Zone Blood } \\
\text { Donation }\end{array}$ & Regulation & $\begin{array}{l}2015 \text { (2019 } \\
\text { Amendment) }\end{array}$ & $\begin{array}{l}\text { Shenzhen's Standing } \\
\text { Committee of the } \\
\text { National People's } \\
\text { Congress }\end{array}$ & VNBD incentives \\
\hline & $\begin{array}{l}\text { Measures of Nanning for } \\
\text { rewarding blood donation }\end{array}$ & Rules & 2017 & $\begin{array}{l}\text { Standing Committee } \\
\text { of Nanning Municipal } \\
\text { People's Government }\end{array}$ & $\begin{array}{l}\text { VNBD incentives and } \\
\text { rewarding }\end{array}$ \\
\hline
\end{tabular}

${ }^{\text {a From }} 1996$ to 2013 the national health administration department of China is The Ministry of Health, and it was revoked and replaced by The National Health and Family Planning Commission from 2013 to 2018. Since March 2018, it was replaced by The National Health Commission

reaching 1.54 million in 2017 [38]. In 2018, a total of 1.84 million units of blood were allocated across the country, of which 1.585 million units $(86.1 \%)$ were allocated between the cities in the same province and 255 thousand units (13.9\%) were allocated between provinces. The policy of raising an alarm regarding the need for blood and deploying it effectively ensured clinical blood supply in need-intensive areas and for major public health events [11].

\section{The rise and fall of FRMBD in VNRBD}

Since 1998, according to Article 15 of the Blood Donation Law, patients' family members, relatives, friends, and colleagues have been allowed to donate blood for mutual aid in emergency situations. FRMBD is a doubleedged sword for blood donation. On the one hand, it can solve the shortage of blood. On the other hand, the risk of blood trade exists in mutual blood donation. The WHO has stressed that when mutual blood donation accounts for more than 5\% of unpaid blood donation, there is a risk of illegal blood trade.

As a specific mode of donation, it was able to relieve the shortage in clinical blood in China. FRMBD accounted for $0.41 \%$ of the national blood collection in 2009 [39]. In 2015, it increased to 4.2\% (see Fig. 3) nationwide. In some provinces, it was significantly higher, such as in Hainan (35.6\%), Guangxi (25.9\%), Xinjiang (11.7\%), Gansu (9.5\%), and Guangdong (9.3\%) [40]. In

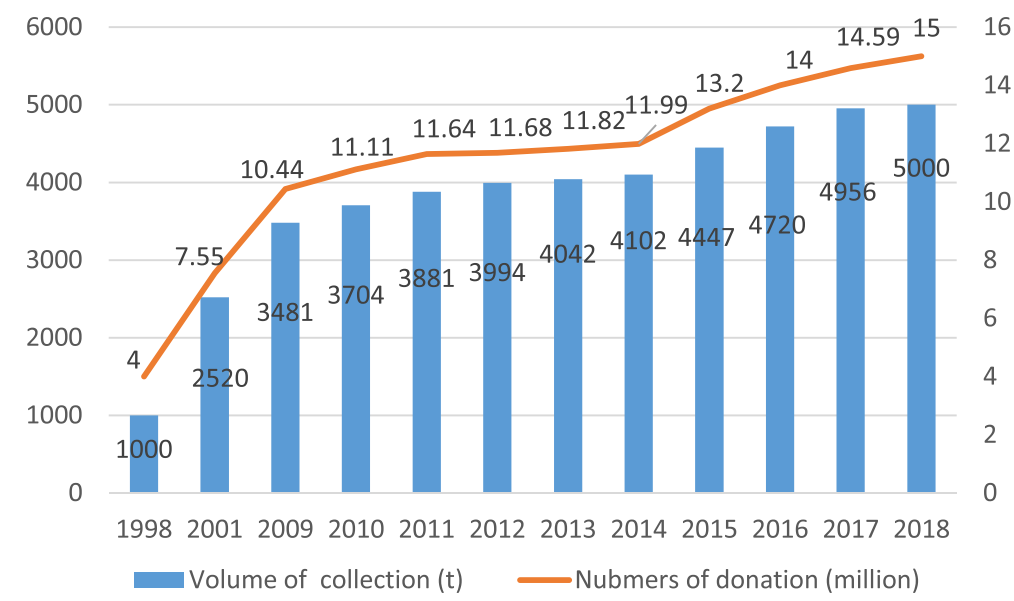

Fig. 2 Numbers of Donors \& Volume of Donation from 1998 to 2018 
Xinning City of Guangxi Province, it was up to more than $50 \%$ [41], while it was $21 \%$ in Beijing in 2017 [42].

However, the rules for mutual blood donation in the Blood Donation Law are too wide in scope for FRMBD and leave room for criminals to sell blood illegally, thereby increasing people's distrust regarding voluntary blood donation and lowering the quality and safety of donated blood [43]. Private transactions between donors and recipients cannot be supervised by medical institutions or blood centers.

To ensure the quality and safety of blood collection, the NHC issued a government order to cancel FRMBD nationwide, except for some remote areas, by March 2018 [27]. At present, most areas have completely stopped FRMBD. There is no doubt that the cancellation of blood donation imposes a burden on the clinical blood shortage in hospitals [44]. In response to this, VNRBD should be promoted and inter-provincial transfers of blood should be properly allocated to maintain the balance of blood supply and demand.

\section{Development of blood safety in China}

Blood safety, to a large extent, depends on whether the blood source is safe. Ensuring the safety of blood collected is the first step in the process. It took the Chinese government four years to establish and strictly implement the testing procedures, and they have been continuously improving it over the past two decades.

China's commercial plasma selling emerged in the early 1980s [45]. Since 1993, blood donors have been required to be tested for HIV, hepatitis B, hepatitis C, and syphilis in order to reduce infections through transfusion according to the Health Examination Standards for Blood Donors [32]. However, these regulations were not fully implemented, and HIVpositive individuals could enter the blood plasma collection process without HIV testing. From the end of 1994 to the beginning of 1995, local outbreaks of the infection started occurring in certain provinces including Hebei, Anhui, and Henan. This HIV epidemic was subsequently found to have originated among plasma donors [45]. It was reported that 326 patients from whom blood was donated at plasmapheresis centers in Hebei Province were identified as HIVpositive during 1995-2013. These HIV infections were proven to have started in October 1994 [2].

Finally, the Technical Operation Procedures in Blood Stations standardized donor screening, which has become an essential testing step at blood collection centers since 1997 [46]. From then on, each unit of blood has had to be tested for blood grouping, hemoglobin, alanine aminotransferase (ALT), and HBV surface antigen (HBsAg) before collection. Donated blood (post-collection) has to undergo comprehensive donor testing twice, using different equipment and/or different personnel, including HIV, HBV, hepatitis C virus, ALT, and syphilis [47].

In the following two decades, testing was strictly implemented. Equipment and technology were updated continuously. For blood group, the RhD type has been mandatorily appraised since 2012 [48]. For serum markers, the colloidal gold strip method was used to detect HBV markers in the early 1990s. Since 1997, serum markers have been tested using an enzyme-linked immunosorbent assay (ELISA) reagent [46]. Since 2010, the Chinese government has established the NAT system in several regions, such as Beijing and Shanghai, covering all types of donations and making great progress in improving blood safety [49]. Due to huge operating costs and the shortage of

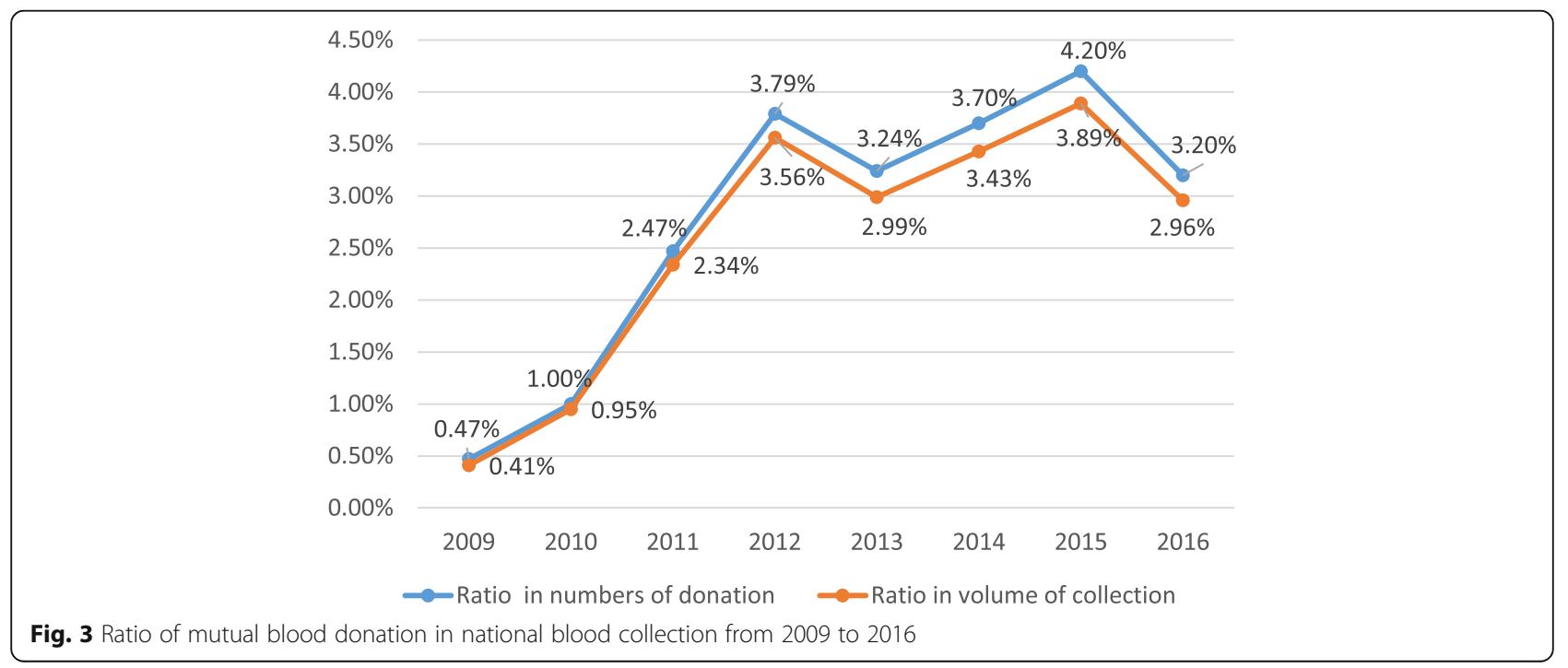


qualified staff in blood centers, NATs were mainly implemented at the provincial level of blood centers in 2013 [15]. In 2014, the blood tests completed using NAT nationwide approached 4.7 million units, which accounted for $36 \%$ of annual blood donations [16]. About 129 million dollars were invested in the nationwide expansion of NAT in 2015 [50]. Eventually, NAT and chemiluminescent immunoassay (CLIA) were formally added to this procedure, according to the Technical Operation Procedures for Blood Centers (2015 Edition) [51]. In order to simplify the procedure and improve its efficiency, serum markers only need to be detected once by ELISA or CLIA except NAT since 2019 [52]. As shown in Fig. 4, the window of HIV, HBV, HCV is shortened when using NAT from 50,72 , and 22 days to 25,59 , and 11 days, respectively [53].

By analyzing the litigation related to transfusion from 1981 to 2020, we found that the number of cases experienced a huge reduction, since $\mathrm{HCV}$ was required to be tested for in 1994 (Fig. 5). Adverse reactions to blood transfusions accounted for $5.6 \%$ of all documents, HBV infections accounted for 5.3\%, HIV infections accounted for $11.0 \%$, HCV infections accounted for $76.7 \%$, and syphilis infections accounted for $2.3 \%$. $\mathrm{HCV}$ infections took the largest share, $55.8 \%$ of which occurred before 1994 .

\section{Transformation of liability in blood transfusion malpractice}

Process optimization and technology updates have improved blood safety directly, but the risk of blood transfusion cannot be eliminated completely for some unpredictable factors such as infections, venous thromboembolism [54], transfusion-related lung injury, and transfusion-associated graft-versus-host disease [55]. Therefore, who undertakes this liability is crucial.

Before 1993, there were no regulations related to adverse events caused by transfusion. For instance, medical institutions or blood stations would not be held accountable for HIV infections caused by blood transfusion because the HIV antibody was not required to be tested for until 1993 [46]. Between 1993 and 2002, there were no laws or regulations to compensate for the adverse events caused by blood transfusion, leaving the issue to be addressed by civil law. The judgment results often depended on the opinions of judges and juries.

Between 2002 and 2010, according to Article 33 of the Regulation on the Handling of Medical Accidents, the fault liability principle was deemed applicable in transfusion. It was found that hospitals were not responsible for no-fault transfusion [56], meaning that the hospital does not bear legal responsibility as long as the process meets inspection standards and the technical index, despite the unfavorable consequences caused by infections resulting from blood quality. Moreover, in case of emergency, infections caused by blood transfusion were exempted on the principle that life extension was more important than longterm quality of life. Obviously, this was not fair for the patient who received HIV or HBV infections through transfusion. Thus, in judicial practice, hospitals were ordered to pay compensation patients in cases of infection regardless of whether the transfusion process was in error, for the sake of fairness [57]. Of the 301 cases, 236 hospitals or blood stations

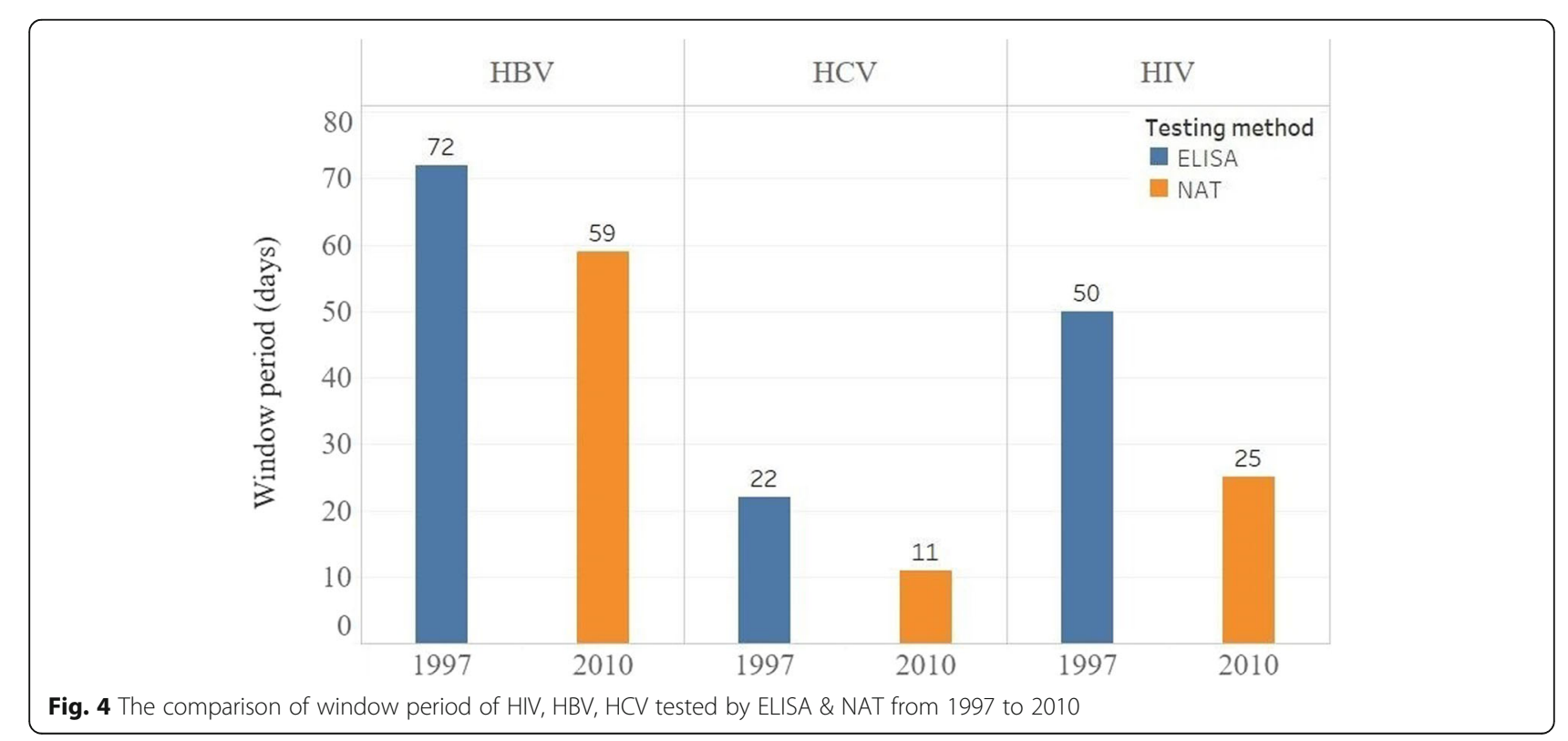




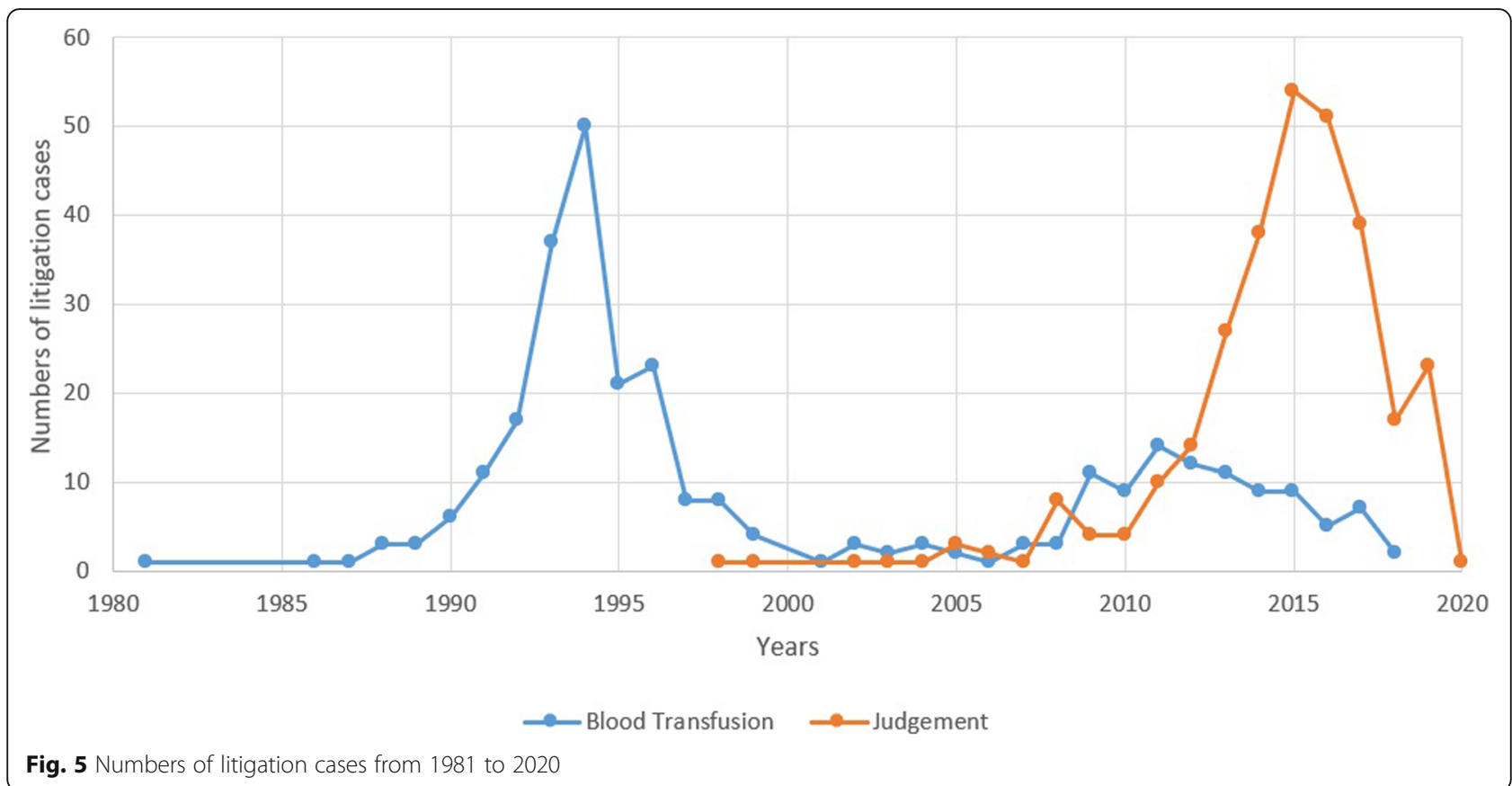

in China paid compensation for infections related to transfusion from 1981 to 2018.

After 2010, according to Article 59 of the Tort Law of China, damage from transfusion was classified as a special no-fault liability tort. It was the first time it was clearly defined that patients could claim compensation. This principle instituted the protection of the rights and interests of patients. Although the hospital may not be at fault in the whole process, they should assume tort liability for infringing upon a civil right or interest of the patient and pay compensation. As shown in Fig. 5, the number of decisions reached its peak in 2015, which is significantly due to the Tort Law of China. Generally, the trial process takes three to 4 years after prosecution. Basically, the patient has the right to claim compensation from the blood center or the hospital if he or she suffered any adverse event due to transfusion or infected blood.

\section{Discussion}

\section{The legal framework promoting the development of} VNRBD

The management of blood donation is an essential part of the public health system and is mainly managed and supervised by the government. Laws and regulations play an important role in blood accessibility and safety. First, the legal framework of blood donation, especially the encouragement of VNRBD, assures the supply for clinical blood use. Second, the legal framework ensures blood safety for all [58]. The rules on blood collection, blood centers, blood tests, and standard operating procedures assure the health rights of blood donors and blood users. Third, a well-established legal framework promotes the uniformity of standards and consistency in the quality and safety of blood and blood products [59].

\section{Contribution of hospitals in improving blood safety}

Blood transfusion therapy is of great significance to the treatment of trauma, anemia, and blood system diseases. Every recipient's blood group must be determined before transfusion. Application of $\mathrm{ABO}$ blood group positive and negative typing and crossmatching tests help avoid acute hemolytic reactions to a large extent. Hemolysis by incompatibility, due to anti-erythrocyte antibodies, remains the most frequent and serious immunological risk to the receiver, especially in a transfusional or feto-maternal context [60]. For some special patients, the Coombs test and an antibody screening test for the detection of irregular antibodies are necessary according to the specifications for clinical transfusion technology [61].

No-fault liability trend in the protection of patients' rights in blood transfusion malpractice

The principle of no-fault liability actually protects the interests of patients, given that they are a vulnerable group to a large extent; however, it places a huge economic burden on public service agencies such as hospitals and blood centers. The brief infectious period, before the virus is detected, cannot be completely avoided. 
Moreover, infection caused by transfusion is generally not detected immediately after transfusion. As a result, loss of blood samples or sample collection errors are commonly found during the investigation of infection cases $[62,63]$. In the absence of conclusive evidence, judges would deduce that the blood or blood products offered by hospitals or blood centers were not qualified and standardized if the patient's family members did not have HCV. Although the retention of blood specimens has been lengthened to 2 years after transfusion, in accordance with the Measures for the Administration of Blood Centers in 2017, it is still difficult to ensure the integrity of the evidence. The final decision depends, largely, on the judge's inference. In brief, the no-fault liability is a strict liability for hospitals, even though a hospital has the right of recourse against the blood center if it fully complies with transfusion standards.

\section{Encouraging blood donation and saving clinical blood use to solve the blood supply shortage}

It is evident that China has made significant advancements in increasing blood donation. To achieve a selfsufficient blood supply, the WHO states that a minimum of 20 to 25 donors for a population of 1000 is essential [59]. With 15 million donations and a population of 1.39 billion, China has a rate of 11 donors per 1000, far below WHO recommendations and those of high-income countries (39.2 donors per 1000) [40, 64]. The NHC authority expects to reach 15 donors per 1000 by 2020 [65]. There are two main measures to sustain the supply of blood. First, incentive policies are introduced to encourage blood donors. Liu's research suggests that, aside from promoting public awareness about blood donation, blood traceability during collection, transportation, and storage can increase trust in the relationship between donor and blood center [66]. On the other hand, saving clinical blood is also important to maintain the blood supply; for instance, reducing the number of unnecessary transfusions and increasing pre-operative autologous blood donation.

\section{Suggestions on the abolishment of mutual blood donation in the blood donation law}

In order to prevent blood dealers from profiting from mutual blood donation, the NHC adopted the most direct and effective strategy. Obviously, there are contradictions and conflicts between the requirements and provisions of the NHC in the cancellation of mutual blood donation. First, the cancellation of mutual blood donation has increased the burden of clinical blood shortage while reducing potential transactional crimes between donors, recipients, and blood dealers. Second, mutual blood donation is allowed and institutionalized by the Blood Donation Law; however, the NHC tried to override it by the notice issued in 2018 [27]. The notice is merely a departmental regulation formulated within the authority of the NHC, with a lower rank and limited authority. The inconsistency of laws and regulations makes it difficult to judge the legality of mutual blood donation. Therefore, under the existing legal framework, there are still legal obstacles in terms of the cancellation of FRMBD [67]. The Chinese government has noticed this situation and is ready to take measures. In March 2019, the NHC decided to revise the provisions on the clinical use of blood in medical institutions to cancel mutual blood donation. We believe that the Blood Donation Law will also be revised to cancel mutual blood donation in the future.

\section{Limitations}

Our study on the development of the Legal Framework on blood donation and blood safety in China is based on data collected from Chinese government websites and the WHO database. The amount of blood donation in the same year may vary according to different data sources. Regrettably, data on the volume of donations from 2002 to 2008 were not obtained because they were not publicly available. Furthermore, the judgment documents related to transfusion were collected from the website China Judgments Online. Due to the irregularity of court records in various regions, there may be some omissions in our data.

\section{Conclusions}

The Chinese government institutionalized the voluntary non-remunerated donation principle, enacted regulations for the management of blood transfusion, and adopted advanced blood testing technology to sustain blood supply and ensure blood safety. The number of litigation cases related to transfusion has experienced a huge reduction since the legal framework and testing technology have improved. Despite increased blood donation, however, blood shortages persist. The quality and safety of blood collection can be further improved through the cancellation of mutual blood donation and incentive measures for the voluntary non-remunerated donation of blood, which need facilitation by governmental legislation.

\section{Abbreviations}

NHC: National Health Commission; NAT: Nucleic acid amplification testing; HIV/AIDS: Human immunodeficiency virus/ acquired immunodeficiency syndrome; HCV: Hepatitis C virus; HBV: Hepatitis B virus; WHO: World Health Organization; VNRBD: Voluntary non-remunerated donation of blood; FRMBD: Family replacement/mutual blood donation 


\section{Authors' contributions}

DG and HL contributed to the project conception and data analysis. DG drafted and revised the manuscript. DG, HL, and WK approved the final manuscript version.

\section{Funding}

This study was funded by grants from the National Natural Science Foundation of China (Grant No. 71804111), Startup Fund for Youngman Research at SJTU, Shanghai Gaoyuan Project for University Academic Program Development (Law Subject), and SHUPL Special Research Project on National Biosafety Legal System (Grant No. 2020YQFK01). The funding agency did not play a role in the design, conduct, or analysis of the research. The decision to submit the manuscript for publication was that of the authors.

\section{Availability of data and materials}

The datasets used and/or analyzed during the current study are available from the corresponding author on reasonable request.

\section{Ethics approval and consent to participate}

This study did not involve any human participants. The data used in our analysis are publicly available. Hence, this study was not considered to require assessment by the ethics review boards of the relevant hospitals.

\section{Consent for publication}

Not applicable.

\section{Competing interests}

The authors declare that they have no competing interests.

\section{Author details}

'Shanghai Jiao Tong University School of Medicine, Shanghai, China. ${ }^{2}$ School of Public Health, Shanghai Jiao Tong University School of Medicine, Shanghai, China. ${ }^{3}$ Law School, Shanghai University of Political Science and Law, Shanghai, China.

\section{Received: 8 May 2020 Accepted: 19 November 2020}

\section{Published online: 30 November 2020}

\section{References}

1. Adams V, Erwin K, Le PV. Public health works: blood donation in urban China. Soc Sci Med (1982). 2009;68(3):410-8.

2. Chen S, Zhao H, Zhao C, Zhang Y, Li B, Bai G, Liang L, Lu X. Eighteen-year follow-up report of the surveillance and prevention of an HIV/AIDS outbreak amongst plasma donors in Hebei Province, China. BMC Infect Dis. 2015;15: 316.

3. Shan H, Wang JX, Ren FR, Zhang YZ, Zhao HY, Gao GJ, Ji Y, Ness PM. Blood banking in China. Lancet (London, England). 2002;360(9347):1770-5.

4. Qian HZ, Vermund SH, Wang N. Risk of HIV/AIDS in China: subpopulations of special importance. Sex Transm Infect. 2005;81(6):442-7.

5. Wu Z, Sullivan SG, Wang Y, Rotheram-Borus MJ, Detels R. Evolution of China's response to HIV/AIDS. Lancet (London, England). 2007;369(9562): 679-90.

6. Sun X, Lu F, Wu Z, Poundstone K, Zeng G, Xu P, Zhang D, Liu K, Liau A. Evolution of information-driven HIV/AIDS policies in China. Int J Epidemiol. 2010;39(Suppl 2):ii4-13.

7. Wu Z, Rou K, Detels R. Prevalence of HIV infection among former commercial plasma donors in rural eastern China. Health Policy Plan. 2001 16(1):41-6.

8. WHO Guidelines Approved by the Guidelines Review Committee. In Towards 100\% Voluntary Blood Donation: A Global Framework for Action. Geneva: World Health Organization Copyright (c) World Health Organization 2010; 2010.

9. Blood Safety. www.wpro.who.int/china/mediacentre/factsheets/blood_ safety/zh/.

10. Yang BC, Shao CP, Zhang YY, Kong L, Xu YP. Two decades of voluntary nonremunerated blood donation in Shenzhen, China. Transfusion. 2015; 55(5):1108-14

11. Regular Press Conference of National Health Committee on June 10, 2019. http://www.nhc.gov.cn/yzygj/xxgzdt/201906/14aedfcb64b044a6af5b68725 7a7e041.shtml.
12. Global Status Report on Blood Safety and Availability 2016. 2017.

13. Shi L, Wang JX, Stevens L, Ness P, Shan H. Blood safety and availability: continuing challenges in China's blood banking system. Transfusion. 2014; 54(2):471-82.

14. Shi L, Wang J, Liu Z, Stevens L, Sadler A, Ness P, Shan H. Blood donor management in china. Transfus Med Hemother. 2014;41(4):273-82.

15. Yin YH, Li CQ, Liu Z. Blood donation in China: sustaining efforts and challenges in achieving safety and availability. Transfusion. 2015;55(10): 2523-30.

16. Yu X, Chen W, Liu Z, Huang Y. Safety and current status of blood transfusion in China: an update. Lancet Haematol. 2016;3(2):e60-2.

17. Zhu Y, Xie D, Wang X, Qian K. Challenges and research in managing blood supply in China. Transfus Med Rev. 2017;31(2):84-8.

18. Dhingra DN. Expert Consensus Statement on achieving self-sufficiency in safe blood and blood products, based on voluntary non-remunerated blood donation (VNRBD). Vox sanguinis. 2012;103(4):337-42.

19. Hong $Y$, Huang $X$, Ling $H$, Liao $H$. Prevalence and trend of HIV infection among voluntary blood donors in China since implementation of the blood donation law: a systematic review and meta-analysis. Trop Med Int Health. 2012;17(8):978-88

20. Tison GH, Liu C, Ren F, Nelson K, Shan H. Influences of general and traditional Chinese beliefs on the decision to donate blood among employer-organized and volunteer donors in Beijing, China. Transfusion. 2007:47(10):1871-9.

21. van der Poel CL, Seifried E, Schaasberg WP. Paying for blood donations: still a risk? Vox Sang. 2002;83(4):285-93.

22. Erwin K. The circulatory system: blood procurement, AIDS, and the social body in China. Med Anthropol Q. 2006;20(2):139-59.

23. Zaller N, Nelson KE, Ness P, Wen G, Bai X, Shan H. Knowledge, attitude and practice survey regarding blood donation in a Northwestern Chinese city. Transfus Med (Oxford, England). 2005;15(4):277-86.

24. Wenjuan M. Analysis of the influencing factors of blood disqualification of individual and group voluntary blood donors. In: The 14th China symposium on integrated traditional Chinese and Western medicine experimental medicine. Shandong: Chinese Association of Integrative Medicine: 2017. p. 190-8.

25. Yueguo Z, Wei W, Dakang C. Function and management in group voluntary blood donation(Chinese). Chin J Blood Transfus. 2014;27(11):1197-9.

26. Law of the People's Republic of China on Blood donation. In: Edited by Congress SCotNPs, vol. Art 15; 1998.

27. Notice on Doing a Good Job in Medical Safety Management during the 19th National Congress. http://wjw.wulanchabu.gov.cn/information/wsj1141 8/msg1130857094815.html.

28. Measures for the Administration of Blood Centres (2017 Amendment). In: Edited by NHC, vol. Art41; 2017.

29. Ping $\mathrm{H}$, Xing N. Blood shortages and donation in China. Lancet (London, England). 2016:387(10031):1905-6.

30. Provisions on Institution of Collection and Supply of Blood and Administration of Blood. 1993, Art3.

31. Measures for the Administration of Blood Stations(for Trial Implementation). In: Edited by Health TMo, vol. Art6; 1998.

32. Provisions on Institution of Collection and Supply of Blood and Administration of Blood. In: Edited by Health TMo, vol. Art2; 1993.

33. Measures for the Administration of Blood Stations(for Trial Implementation). In: Edited by Health TMo, vol. Art27,33; 1998.

34. Law of the People's Republic of China on Blood donation. In: Edited by Congress SCotNPs, vol. Art12,13; 1998.

35. Yu C, Holroyd E, Cheng Y, Lau JT. Institutional incentives for altruism: gifting blood in China. BMC Public Health. 2013:13:524

36. Xinhua website. The number of unpaid blood donors and blood collection in China has been increasing for 20 years. 2019. http://www.xinhuanet.com/ politics/2019-06/11/c 1124607998.htm.

37. WHO. List of countries reported collection of blood from $100 \%$ (or almost $100 \%$ ) voluntary nonremunerated blood donors (in alphabetical order). 2013. https://www.who.int/campaigns/world-blood-donor-day/2013/blood_ donor_countries.pdf.

38. Office of the National Health Commission. Notice on 2017 national blood safety technical verification. 2018. http://www.nhc.gov.cn/xxgk/.

39. Jie M. Brief analysis of different blood donation models for voluntary blood donation in China from 2009 to 2014(Chinese). Chin J Blood Transfus. 2017; 30(07):766-8. 
40. Circular of the General Office of the National Health and Family Planning Commission on Blood Safety Technical Verification in 2016. http://www.nhc. gov.cn/yzygj/s7658/201704/5eb5a939a0bd4ba9921f8a3eec46e318.shtml.

41. Jiaxin L, Hongwu G, Jun S. Annual Report on Development of Chinese Blood Collection and Supply Industry 2017 (Chinese). In., 2017 edn, vol. 55; 2017. p. 415.

42. There will be 16 more blood collection points on the streets in Beijing this year. https://new.qq.com/omn/20180213/20180213A0G1QJ.html.

43. Yongjun CRL. Research on the clinical application of mutual blood donation system in blood source tension period(Chinese). Clin Res. 2019;27(06):7-9.

44. Yun-long H. Try to talk about the confusion and outlet of mutual blood donation(Chinese). J Nanjing Med Univ (Social Sciences). 2013;13(03):219-21.

45. Guo Z, Xiao D, Xu S, He K. Analysis and forecast of the HIV/AIDS epidemic in Mainland China, 1985-2016. J Public Health (Oxf). 2019:fdz1 16. https://doi. org/10.1093/pubmed/fdz116.

46. Technical operation procedures in blood stations In: Edited by Health TMo, vol. 1997; 1997.

47. Li L, Li KY, Yan K, Ou G, Li W, Wang J, Song N, Tian L, Ji X, Chen Y, et al. The history and challenges of blood donor screening in China. Transfus Med Rev. 2017:31(2):89-93.

48. Technical operation procedures in blood stations(2012 Edition). In: Edited by Health TMo, vol. Art4.11; 2012

49. Cai LN, Zhu SW, Zhou C, Chen BA, Sun J. Analysis on HIV infection status of voluntary blood donors in Chinese Nanjing area from 2003 to 2013. J Exp Hematol. 2014;22(5):1422-7.

50. Notice of the General Office of the National Health and Family Planning Commission and the General Office of the Ministry of Finance on Nucleic Acid Test in Blood Stations. In: NHC; 2015 .

51. Technical operation procedures in blood stations In: Edited by Health TMo, vol. Art4.1; 2015

52. Technical operation procedures in blood stations(2019 Edition). In: Edited by Comission NH, vol. Art4.2; 2019.

53. Jiang Q. Study on the relationship between ELISA and NAT in blood HBV screening(Chinese). Zhejiang Med J. 2019;41(12):1322-4.

54. Thurn L, Wikman A, Lindqvist PG. Postpartum blood transfusion and hemorrhage as independent risk factors for venous thromboembolism. Thromb Res. 2018;165:54-60.

55. Bolton-Maggs PHB, Watt A. Transfusion errors - can they be eliminated? $\mathrm{Br}$ Haematol. 2020;189(1):9-20.

56. Regulation on the Handling of Medical Accidents. In: Edited by Health TMo, vol. Art33,49; 2002

57. Li H, Zhao X, Li W, Zhao H. Claims and compensation for complications resulting from blood transfusions in China from 1998 to 2013. Transfus Apheresis Sci. 2015;53(3):329-36.

58. The function and significance of promulgating and implementing the blood donation law. http://www.csbt.org.cn/plus/view.php?aid=6347.

59. Blood safety and availability. https://www.who.int/en/news-room/factsheets/detail/blood-safety-and-availability.

60. Mannessier L. Roubinet F, Delamaire M, Chiaroni J, Lejealle A. Analytical validation in erythrocyte immunohematology. Transfus Clin Biol. 2000; 7(Suppl 1):51s-4s.

61. Möhnle P, Humpe A, Wittmann G. When a is not a anymore: problems and pitfalls with blood group typing. Anaesthesist. 2018;67(9):637-46.

62. Sharma RR, Kumar S, Agnihotri SK. Sources of preventable errors related to transfusion. Vox Sang. 2001;81(1):37-41.

63. Fastman BR, Kaplan HS. Errors in transfusion medicine: have we learned our lesson? Mt Sinai J Med. 2011;78(6):854-64 New York.

64. Wang Y, Wu Y, Chen Y, Li C, Lu L, AuBuchon JP, Liu Z. The journey toward safer and optimized blood service in China: national strategy and progress. Transfusion. 2016:56(12):3112-20.

65. Opinions on further strengthening blood management. http://www.csbt. org.cn/plus/view.php?aid=168.

66. Liu Chang Q, Shi Xiao F. Study on the revision and improvement of the blood donation law of China: From the perspective of the formation of the dilemma of free blood donation and legal response (Chinese). Qinghai Soc Sci. 2013;05:69-74.

67. Ming-feng Z. Legal Ethics Reflection on Withdrawn of Regulation on Mutual Blood Donation(Chinese). Med Philos. 2018;39(12):23-5.

\section{Publisher's Note}

Springer Nature remains neutral with regard to jurisdictional claims in published maps and institutional affiliations.

\section{Ready to submit your research? Choose BMC and benefit from:}

- fast, convenient online submission

- thorough peer review by experienced researchers in your field

- rapid publication on acceptance

- support for research data, including large and complex data types

- gold Open Access which fosters wider collaboration and increased citations

- maximum visibility for your research: over $100 \mathrm{M}$ website views per year

At BMC, research is always in progress.

Learn more biomedcentral.com/submissions 